\title{
Gender equality policy in Georgia and challenges
}

\begin{abstract}
Scientific research confirms that equal opportunities for girls and boys is one of the most important determinants of development, which has a positive impact on the country's progress in all vital areas, the country's economy, politics and social life.

The paper "Gender equality policy in Georgia and challenges" combines a mixed study to explore important aspects of gender equality principles in Georgia a variety of areas, including women's political involvement, quotas and mechanisms during elections, domestic violence and violence against women. Prevention, premature marriage as a form of violence.

Public or non-governmental institutions working on these issues, research of state programs, which programs help citizens in involvement and development, empowerment of women and rural women, and economic prosperity. Georgian legislation, as well as gender budgeting and programs were studied.

The data obtained from the studies give us a basis to draw the following conclusions:

1. Despite the positive general legal framework, Georgia fails to meet its international commitments in practice to uphold the principles of equal rights for women and gender equality.

2. Quotas system and mechanisms have been improved in Georgia again.

3. Georgia still lacks shelters and services for victims of violence.

4. There are no solid coordination mechanisms between the state agency and local self-governments.

5. Public servants need to acquire additional knowledge and experience on gender sensitivity, budgeting and program planning.
\end{abstract}

Key words: gender, gender policy, Georgia, legislation

\section{Introduction}

$\mathbf{T}$ he thesis "Gender equality policy in Georgia and challenges" provides a political, cultural and social overview of the current gender reality in Georgia. The thesis addresses the following topics: legislative mechanisms in Georgia and their implementation in local government, women's political involvement, quotas and the electoral system, women's economic empowerment and the exchange of best practices in gender policy. The thesis will also discuss challenges in Georgian reality and visions.

Any state that wants to address gender and women's issues must develop a special strategy. The implementation of a relevant strategy developed by the state must be supported by local government. All state institutions must take special responsibility for the implementation of the gender strategy.

Gender equality is a principle of a democratic society. Discussion of gender issues requires clarification of the term "gender" - it is a social role that refers to psychological, cultural and social characteristics. Gender theory, on the other hand, is a methodology for the analysis of gender characteristics and relations, which focuses on the analysis of the consequences of gender differentiation and hierarchy. 
Gender issues have always been at the centre of attention of researchers, who have different opinions and explanations about them. For example, one of the tasks of gender psychology is the study of gender identity, the study of the mechanisms of its construction in different times and socio-cultural contexts, also in the context of social change. The starting point for gender psychology is social-constructivist concept, which focuses on the social world through the human construct.

From the perspective of gender constructionism both gender and sex are socially attainable statuses. Every human life is shaped by socio-cultural norms and rules (Lorber, Farell, 1991). There are no gender-homogeneous societies or ethnic groups; from the first minute after birth we create gender by indicating which child is a boy and which child is a girl. We wear different coloured clothes and in every way we support the creation of differences. There is a "taboo about the similarity of boys and girls".

\section{Analysis of the gender problem in the Georgian reality}

Gender equality means equal representation of women and men in the process of social, political, economic and cultural development. Gender equality is one of the essential features of a society based on democratic values and principles of social justice. Gender equality means that women and men have equal conditions and opportunities in life to recognize their full potential, participate equally in the political, economic, social and cultural development and benefit equally from public goods, opportunities and resources. Gender equality does not mean that women and men are identical; on the contrary, it is recognized that people have different values and goals, different needs and lifestyles in a democratic pluralistic society. Nevertheless, their interests should be given equal consideration at all levels and they should enjoy equal rights and opportunities and have equal duties and responsibilities.

According to the global gender index Georgia ranks $84^{\text {th }}$ out of 134 countries in terms of gender equality. It is outranked by such countries as Ukraine and Moldova. But then Georgia is a patriarchal country, where the man is the main decision-maker. If a woman wants to achieve self-accomplishment, she must take over the functions of housewife and mother. The family is all that matters for a woman in Georgia - she should be involved only in raising children and taking care of the house, and not focus on her professional development. Naturally, this opinion is shared mostly by men $(72 \%)$, and less frequently by women (52\%). The study shows that taking care of the family is the most important role in a woman's life. $91 \%$ of women and $93 \%$ of men fully or partially agree with this opinion. In addition, the survey results show that according to $79 \%$ of the respondents, the woman's family and not her success at work is the only criterion a woman's recognition. Furthermore, the majority of respondents ( $72 \%$ ) believe that a man's duty is to work and provide for his family, while a woman's duty is to take care of the home and family. This opinion is shared by $66 \%$ of women and $80 \%$ of men. According to the survey, traditional Georgian ideas and customs describe a Georgian woman as an obedient wife, housewife and mother. A woman's work and career is considered less important. It is believed that a woman can fully accomplish herself as a result of getting married and combining the roles of wife and 
mother, whereas for a man, career and work are either equally important or even more important.

On a social level, on the other hand, women are required to obey a man, to follow his wishes and desires and to put their own requirements aside. Moreover, in culturally conservative Georgia, the lack of success of women in the labour market is explained by the choices made by women themselves. Proponents of this opinion believe that it is much more desirable for women to have less active and even less prestigious professional roles in order to devote more time to family and children.

Early marriages, abduction of girls for marriage (mainly in minority communities) and domestic violence are still widespread phenomena in Georgia. One in twelve women is a victim of physical assault by her husband/partner and over $35 \%$ are affected by various forms of violence, including psychological, verbal and economic; Georgia is the leading country in the world in terms of sex-selective abortion, i.e. termination of pregnancy based on the expected sex of the child. Sex-selective abortion stems from the tradition - it is more desirable to give birth to a male child because, as corroborated by various studies, a male child is considered to be a natural "heir" to the family wealth. As a result, thousands of female foetuses become victims of abortion every year.

Women are also poorly represented in public life: women's representation is minimal in the Parliament of Georgia (only 9 women out of 150 deputies), in the executive (only 3 women out of 18 ministers) and in the private sector. Although the percentage of women employed in private institutions is high, most of them occupy lower-level positions; while most decision-making positions belong to men (e.g. 2318 men and 298 women are represented in senior positions in the public sector).

\section{Overview of Georgian legislation}

The formation of the legal basis for ensuring gender equality in Georgia began with the restoration of Georgia's statehood. From 1991 to the present day, Georgia has ratified all basic international declarations, conventions, treaties and agreements that oblige signatory states to ensure and protect gender equality. Georgia has adopted special laws aimed at ensuring gender equality and eliminating discrimination, and has made relevant amendments to Georgian legislation and subordinate acts. The creation of a legal basis is important, but it is not necessary to ensure gender equality.

On 15 September 1991, the Supreme Council of Georgia ratified the Universal Declaration of Human Rights. In 1994 the Parliament of Georgia ratified the Convention on the Elimination of All Forms of Discrimination against Women, and in 2001 the 1999 Optional Protocol to the Convention was ratified. The Convention against Discrimination in Education entered into force in Georgia in February 1993, and the International Covenant on Civil and Political Rights was enacted on 3 August 1994. Decree N 153 of the Parliament of Georgia of 29 May 1996 ratified the Convention concerning Equal Remuneration for Men and Women for Work of Equal Value. On 22 June 1997, the Convention on Discrimination in Employment and Occupation, ratified in 1995, entered into force in Georgia. In 1999, the Convention for the Protection of Human Rights and 
Fundamental Freedoms was ratified. On 16 December 2005, Georgia acceded to Convention N 2613 on the Political Rights of Women. On 7 June 2006, the Parliament of Georgia ratified the Protocol to the United Nations Convention against Transnational Organized Crime Protocol to Prevent, Suppress and Punish Trafficking in Persons, Especially Women and Children. On 29 August 2017, the Council of Europe Convention on preventing and combating violence against women and domestic violence was ratified. On 26 March 2010, the Law of Georgia on Gender Equality was adopted. The Law on Elimination of All Forms of Discrimination was adopted on 2 May 2014.

Along with the adoption of legal acts, the presence of institutional mechanisms is essential for the implementation of normative acts. Gender equality is a complex issue that relates to all areas of life, therefore its comprehensive implementation would not be possible without special and efficient institutional mechanisms. The first special institution to ensure gender equality was established as late as 2004 through the creation of the Consultative Council for Gender Equality under the President of the Parliament of Georgia. However, this institution did not have sufficient legal guarantees. It was only in 2010 that the Consultative Council for Gender Equality under the Parliament of Georgia received legislative recognition under the Law on Gender Equality - the Law stipulated that the Parliament of Georgia "shall establish the Council for Gender Equality to ensure systematic and coordinated work on gender issues." In 2014, amendments were made to the Law on Gender Equality. A new Article 121 was added to the law; according to the new article, a special institute for ensuring gender equality should be established at the representative bodies of the autonomous republics: "The highest representative bodies of the autonomous republics, in accordance with the legislation of Georgia and the autonomous republics, shall establish a Gender Equality Council to ensure systematic and coordinated work with the Gender Equality Council." On 28 April 2016, amendments were made to the Law on Gender Equality. Paragraph 11 was added to Article 13 of the Law, which stated the following: "11. Gender Equality Council to ensure systematic work on gender issues in the municipality and coordinated cooperation with the Gender Equality Council established by the Parliament of Georgia." Thus, by 2016, special institutions were established at the central, autonomous republic and local levels to ensure gender equality. However, in all these cases, the law provided for these institutions to exist at the representative body only. Indeed, the presence of such institutions is necessary at the representative bodies, since it is the representative bodies (parliament, the Supreme Court, municipal assembly) that define the basic orientations of the gender equality policy of the state/autonomous/urban republics and ensure the normative supply of the qualitative process. However, it is also important that similar institutions are present at the executive level, which has the task of implementing this policy. A corresponding amendment was introduced to the Gender Equality Act as late as 4 May 2017. A new paragraph 6 was added to Article 12 of the Law, according to which "the Government of Georgia shall establish the Interagency Commission on Gender Equality, Violence against Women and Domestic Violence to ensure systematic and coordinated work on gender and other issues provided for by the legislation of Georgia." Based on this requirement of the law, Decree N286 of the Government of Georgia dated 12 June 2017 on "Establishment of the Inter-Agency Commission on Gender Equality, Violence against Women and Domestic Violence and Approval of its Statute" was adopted. The Inter-Agency Commission started its activity under this Decree; one of the main tasks 
of the Commission's activity is "to act as a coordinating body that will be responsible for coordinating, implementing, monitoring and evaluating policies and measures aimed at preventing and eliminating all forms of violence within the scope of the Council of Europe Convention on Preventing and Combating Violence against Women and/or Domestic Violence, of 11 May, 2011 (sub-clause "k" of Article 4 of the provision).

The establishment of this commission was an important step forward in coordinating the activities of the authorities in the process of implementing state policies for ensuring gender equality. As a result of the amendments made to the Gender Equality Act between 2010 and 2017, the following institutional structure for ensuring gender equality has taken shape at the central and the municipal levels with the following institutions operating at the central level:

- the Permanent Parliamentary Council for Gender Equality;

- the Inter-Agency Commission on Gender Equality, Violence against Women and Domestic Violence; and

- the Gender Department of the Public Defender's Office of Georgia.

There is only one institution operating at the local level, namely:

- the Municipal Gender Equality Council.

However, at the local level (particularly in municipalities) there are persons to whom responsibilities in the area of gender equality have been assigned. There is also the State Representative's Administration for Local Governments and Gender Policy.

\section{Gender and self-governance in Georgia}

The local government policy document of 2014 provides for the promotion and support of gender equality. In 2014 the Law of Georgia on the elimination of all forms of discrimination was approved. Georgia has repeatedly referred to women's rights and gender equality on the international arena and made commitments to take effective steps towards achieving gender equality. The Government of Georgia has taken steps towards the achievement of gender equality and fulfilling its commitment to this cause. The establishment of councils at state and at the municipal levels is one of such initiatives. A municipal council makes proposals and coordinates its activities with the existing council at the parliament. The function of the local council is to make reports, compile gender statistics, make recommendations and make the institution a mainstream facilitator and decision maker. At the stage of budget planning focus is made on the economics of the programme, its finances, and how the results affect a particular woman or man. All programmes that are planned by the local government have to go through this council. This approach makes the programme more effective. The council also provides opinion on the bills on gender equality submitted to the parliament.

Gender equality is also addressed in the normative acts adopted by the municipal self-governing assembly. These acts are more focused on specific citizens and are more sensitive to their problems. They relate to a specific locality, a specific situation and have a direct impact on the lives of each individual citizen and therefore are more important for them. In a situation when more policy is determined at the state level, the role of the self-government and the council focused on issues related to gender equality 
becomes more important - after all, the local policy is oriented to local needs and takes into account all mechanisms, which are not rigid; they are analyzed in relation to each individual citizen and are adapted to all needs, conditions, traditions, customs, specifics of each citizen and consequently are much more optimal and acceptable. The number of board members in the city council is not defined, but the board has its own statute and this statute defines the powers and the number of members. People are represented by both governmental and non-governmental agencies.

It is also important that local authorities see the need, for example, to create community organisations in an inactive region so that local problems existing there can be addressed more effectively. However, often initiatives aimed at activating women fail. Let me give you one example. There is a programme implemented at the local level called "Development of traditional crafts" (stamping, goldsmithery and felt processing). Traditionally, it is men who do the stamping and women who do the felting. Likewise, goldsmithery is a more masculine task. More funding in the programme is targeted at the more masculine jobs. Therefore, it is difficult (if not entirely impossible) to persuade women to take part in the programme. This shows that if we want such programmes to be successful, less attention should be paid to the financial gain. The local assembly council and the people working on the problems should be brought together before the programme is adopted and analyze it not only form the cost effectiveness point of view but also from the perspective of gender equality. The voice of women should be heard and taken into account. However, the number of women represented in the municipal assembly council is $24 \%$ and only $11 \%$ of them come from rural areas.

Women's political participation should be balanced at the local government level - in the civil service and local government, also in business we often face challenges such as glass ceiling, i.e. a situation where women are not moved to a higher position. Studies show that women perform well in detailed routine tasks but are at a relatively low level in both the public sector and business. They are given less opportunity for promotion, which may be due to a discriminatory environment and, above all, it is believed to be related to cultural norms and views. A woman's reproductive function should not be an obstacle to her career advancement. She should not be forced to demonstrate that she can perform at a high level. Therefore, in the workplace, the labour code must also be adapted so as to give more freedom to the employers in their decision making processes.

Businesses should take part in the process of gender equality. A representative of the business sector should ensure that a woman on maternity leave, taken in order to reproduce, is not a hindrance to the employer. She must be able to advance as a professional and really show that she can perform her duties to a high standard. According to research, women have different problems, for example they need skills, knowledge of business principles, confidence to start a new business. All this is related to social and cultural norms and stereotypes, namely that business is an occupation for men and a woman should take care of the family.

Starting a business is an enormous problem and challenge for women. Seed fund is needed, which every woman in Georgia finds difficult to get. Women do not have their own financial resources, in some cases they do not own property or are formal owners of property. They can apply for a loan to a bank or microfinance organization but there is a problem of security for the loan. Furthermore, women find it very difficult to contrib- 
ute their own assets to a start-up company because they have not sufficient will power to convince their spouses that such decisions will benefit the entire family. Therefore, various raising organizations, including the state, should help women raise funds to start up their own business. Focus on human resource policies is also needed - women need advice and help in hiring employees. They should also be given equal opportunities for promotion.

Women who work in the village on the farm and have children face a different set of problems. If they work, they cannot take their children to a kindergarten because there is no kindergarten in the village. Most institutions for children are located outside the village and women have a long way to get to them. Therefore, the local municipality and council should address this issue and contribute funds to either building or at least renovating a kindergarten garden in the village.

The pre-school system facilitates needy parents to feed their children in a healthy manner, adhere to the rations provided and offered by the state and is effective. But again the issue of gender is forgotten. If only football fields are built, girls will be isolated, deprived of sports and cultural events. The government must focus on state cooperatives. Municipality should allocate money from small grants.

According to the definition of social concepts, the process of human formation is the socialization of the human personality, including the process of combining knowledge, values and norms and consisting of the process of assimilation of laws, behaviours and values. Each person and each gender assimilates them to a different extent; consequently, there is the opportunity to define professions of men and women not by their abilities and suitability but through the prism of gender. Roles are directly related to education, which is explained by gender equality, which includes equal conditions and protection of their rights.

It is remarkable how men define a woman's personality - while they consider themselves to be a full subject, women, on the contrary, are perceived as having fewer opportunities. Problems of gender and inequality are present at work, in employment. Consider the statistics of employees in terms of gender - despite the fact that according to Article 1 of the Law of Georgia on Gender Equality, the state promotes equal access to employment for both genders, the majority of employees in 166 public institutions in Georgia are men. Statistics show that despite the same law and the same article, individuals are put in an unequal position due to their gender or are given an advantage that is justified by the nature and specificity of the work. In Georgia, many more men than women are employed in managerial positions.

Public perceptions and attitudes towards certain areas and issues are largely determined by the degree of involvement of community members in these issues. Surveys on political issues show the extent to which survey participants are interested in civic and political activity. In terms of interest in politics among men and women, slightly more men express interest in politics than women. Both quantitative and qualitative studies confirm that politics is the domain of men, and the public opinion is that a woman's place in politics should be limited. The majority believe that men are generally more suited to political activity than women and their view is that men are better at it than women, and that men are better leaders than women. It is also worth noting that this view is shared by $56 \%$ of women. Qualitative research suggests that men may be more successful in politics, as evidenced by the proportions of activity between the two sexes. Consider 
the situation in Georgia and Poland, in which the issues of political quotas and women's participation at the local government level are also relevant.

\section{Gender quotas in Georgian politics}

In different parts of the world, women are demanding the use of effective methods to achieve gender balance in politics, and the quota system is one such effective mechanism. The idea of gender quotas is based on overcoming the current state of women's isolation from politics and including them in political processes. The quota system places responsibility not on individual women, but on political parties, which control the process of recruitment into politics. Quotas are a temporary measure that remains in place until barriers to women's political participation are overcome. Quotas can be statutory, intra-party or imposed by political parties.

Quotas set by state law are relatively easier to implement for nominations than for elections, as the quota system addresses the fundamentals of democratic processes and may undermine the idea of free choice by voters, although the nomination system remains in the hands of the parties. Mandatory quotas are divided into two parts: the legislative quota and the reserved quota. Reserved quotas are set by a country's constitution and in some cases by electoral law. This system provides for the allocation of certain seats in bodies to women in accordance with the rules laid down in the electoral law. Such a system ensures guaranteed representation of women in parliament.

The first steps towards the introduction of a gender quota system in Georgia were taken in 2011, when the Law on Political Unification of Citizens was amended, introducing a system of financial incentives for political parties. A party that fielded two female candidates for every ten on the proportional list would receive a 10 per cent supplement to basic funding. The budget incentives increased in 2014, but according to the results of a survey, more than half of the Georgian population is represented by only 24 women in parliament. It is particularly encouraging that the issue of women's political participation has moved beyond politicians' rooms and training agendas and that their issues are now publicly and openly discussed. On 12 June 2017, the Working Group on Women's Political Participation once again presented a bill for mandatory gender quotas in parliament. If the initiative is taken up, parties will be obliged to put an equal number of men and women on electoral lists. The 2014 National Democratic Institute survey clearly shows that the attitude of a large part of the public towards political activity between men and women is inconsistent. On the other hand, a large part of the public is in favour of introducing gender quotas to increase the number of women in parliament, although scepticism towards women politicians has persisted until today. In the political space, attitudes towards gender quotas vary. Finally, it must be said that society has to some extent come to the conclusion that women's participation in decision-making is directly linked to the full protection of women's rights and the maintenance of justice in the country, which in turn is a condition for prosperity in the state. Although some parties are strongly opposed to the quota system, it is important to maintain the existing sense of responsibility and solidarity. All those working to achieve gender equality in Georgia should strive to improve the situation of women. Politically, it is difficult to ignore the will of the electorate to see greater progress and equality. 
The existence of majoritarian system and quotas is less important for Georgian society. A voter pays less attention to the role and contribution of a particular person to the society, in fact he votes for the party. And representation is politics remains a problem and it is directly proportional to the economic empowerment. It is unthinkable for a woman to run and win in elections in the majoritarian system. Today, if she does not have the finances for meetings, posters, billboards, there is no political culture in Georgia and there is no readiness in Georgia and there is no readiness in society. Because it is important to introduce quotas, many parties say that it will happen naturally. But if we bet on naturalness, according to current data, Georgia will need 44 years for women to naturally balance the world average of society. If the critical mass (minimum 30\%) is not achieved in the parliament, women will never be able to influence the political process - they are a minority or they are a marginal group that cannot make decisions. This applies not only to the polls but also to the political process. Women are isolated - this is obvious when things happen in the parliament, when there are discussions on issues in which women cannot participate. However, when the critical mass of at least $30 \%$ is achieved, they can be and are united. World practice shows that in a parliament where women's representation is $20 \%$, the parliament starts talking about children's rights. When the representation is $30 \%$ - children's and women's rights are on the agenda, and if the representation is higher, the parliament starts focusing on sustainable development and economic prosperity in general; it is evident that $50-53 \%$ is an exemplary representation, but even a representation of $30 \%$ will have a positive impact on parliamentary decisions. The role of local government is also noteworthy. Women should be more involved in the work of local government and help to decentralize local government activities. Studies have shown that when women are in local government, more problems are solved, at least socio-economically.

There is a gender equality council in parliament. Laws such as domestic violence against women, sexual harassment, are mainly initiated by women and lobbyists in parliament. Likewise, women are also lobbyists in the local government, where they promote projects such as outdoor lighting or widening a footpath (to take a child in a pram); the involvement of men and their sensitivity to such issues is negligible. Therefore, the quota is a tool to increase women's participation in politics by establishing principles of fairness, equality and recognition of rights. For many years Georgia has not achieved results because the quota system was not a tool. It still remains a challenge in Georgia to recruit women to work for the local governments. It is also a challenge that women in local governments have low legitimacy for their actions, so they cannot effectively lead their actions, compared to others. The conditions for women's career development are also unfair, politics in Georgia is masculine and brutal and it requires obedience.

In Georgia there are various factors that support the idea of women's political participation, for example, the different nature of woman; the woman as a weaker being than man; the retention of woman in the family; the specificity of political activity itself; the negative attitude of family members, spouse towards her/his involvement in politics; the low probability of support from voters etc. A more detailed analysis of each of these factors reveals why politics is so much more suitable area for men. 54\% of Georgian population is of the opinion that women are weaker in politics and it is difficult for them to take responsibility for themselves. A considerable number of people believe that due to the weakness of women by nature, politics is an unsuitable field for them and they will 
not be able to adequately cope with the difficulties in this field. A man's involvement in politics reinforces the perception that he is more socially active than women and it is these social contacts that help him achieve political success.

While some respondents believe that the soft nature of female politicians is not the reason for their lack of integrity, many believe that female politicians are lighter than male politicians, so there are risk factors to these assumptions. We can even see that a woman often turns out to be a worse politician than a man.

The above arguments justifying the inappropriateness of politics for women also refer to objective circumstances that may prevent a woman from getting involved in politics. For example, there is a belief that it will be difficult for a woman to succeed in politics because involvement in politics interferes with family life, which upholds the stereotype that the family is a woman's priority and value. The family must stand above her career. Men's involvement in the family is minimal compared to women, and women play a key role, which is also a factor that hinders a woman's political career.

It is also worth noting that a woman's 'married' social status is an issue even when parents do not want their child to be involved and influence the desire to be involved in politics.

The low potential for success in politics for women compared to men is also reflected in the fact that women are supported by fewer voters than men, and while voters are not opposed to women in some policy areas, they believe that men will have more supporters than women. Again, it is the same argument - a woman is a weak phenomenon. It is believed that it is best for a woman to devote her energy and time to her family.

On the other hand, when we compare women's involvement in politics and their readiness to take up business opportunities, it turns out that women's involvement in business is considered more realistic than their involvement in politics. And although the majority of politicians in Georgia come to politics from business, women find it more difficult because women in Georgia have less capital, which is yet another hindering factor for them.

Based on the above factors we can say that while some women thought they might consider running for political positions having been successful in business, which, in their opinion, might be a good start, many of them do not see themselves as active actors on the political arena. This is yet another argument for the low self-esteem of Georgian women.

\section{Gender inequality and violence in Georgia}

Georgia is a country with national minorities. According to the latest census conducted by the Department of Statistics of Georgia, national minorities account for $16.2 \%$ of the total population. The largest ethnic group in Georgia (6.6\%) is the Azerbaijanis, living in the compact area of Kvemo Kartli. The Kvemo Kartli region is located in the south-eastern part of Georgia. The population of Kvemo Kartli as of 2019 is 511.2 thousand, which is $11.4 \%$ of Georgia's population. One Kvemo Kartli region includes 347 settlements, 7 cities, 6 towns and 334 villages. $44.7 \%$ of the population is ethnically Georgian, $45.1 \%$ is Azeri, $6.4 \%$ is Armenian, and 3.8\% is Abkhazian, Ossetian, Russian, Greek, Ukrainian and Kurdish. Kvemo Kartli has some peculiarities - one of them is the predominant view of the dominant role of men in the family. The man is the main dom- 
inator. The culture of Kvemo Kartli is closed and women do not speak out about what is happening to them but it is a fact that men often resort to violence against other family members simply to reinforce their dominance. There are many cases of different forms of violence in the region, such as physical violence, emotional violence and child abuse. This may be due to stereotypes, culture, low levels of education.

The most common form of violence in Kvemo Kartli, and particularly in the Marneuli region is early marriages, which are most often entered into against the will of girls and under pressure from their parents. Kvemo Kartli is a region inhabited by ethnic minorities, and early marriages are still important among ethnic minorities, including in Azerbaijan, where most girls are married before the age of 18, and in some cases before the age of 16. The reason for this is their traditions. The control of women's sex life by society is another factor that promotes early marriage. Social stigma and other social and religious factors should also be taken into account. We should not forget about the economic dependence of women on men, which very often is the reason why women, despite being abused, stay married to their abusive husbands.

As a result of the activities of the Social Service Agency, various shortcomings in this area have been revealed. The Office of the Public Defender of Georgia has prepared and published a special report on "Early marriages - challenges and solutions" (2020). But when parents and children do not express protest or dissatisfaction with the problem of early marriages, social workers consider that a response is not necessary because the child's welfare is protected. The social service agency and schools have difficulties in carrying out the activities provided for by law in regions where ethnic minorities live. The language barrier makes their work much more difficult and often the agency chooses to offer no service. But the lack of service affects vulnerable groups and children, such as victims of violence. On top of that there is no system to collect statistical data about the reasons for dropping out of school by children.

Regional causes of violence are considered to be low economic income, unemployment and poverty, which cause stress and strained relationships between family members. Parents who have experienced violence in the past often become perpetrators themselves. It should be noted that in Georgia it is common practice for parents to legalise property in favour of their son, therefore girls do not have capital and therefore they cannot start their own business, they cannot get credit for a business even if they want to start one, they do not have the economic basis for a bank to give them a business loan, credit. Among other challenges in the region is the lack of public services to address these problems. In particular, people in need do not receive fully-fledged psycho-social services.

In a patriarchal culture, violence is an alternative form of gender selection, also in Georgia. There is a high rate of unborn girls and premature abortions and selection of gender in favour of boys. In the Kvemo Kartli region early marriages and artificial abortions are frequent. There are also reproductive health problems among women who do not consult a doctor for various reasons.

People in the Kvemo Kartli region need to raise their awareness to better understand the problems that can result from early marriage. For example, girls who married young cannot get an education because they have no knowledge, they cannot start a job, have no career prospects. In many cases they become victims of psychological and physical violence by their husbands or other family members. 
There are no cases regarding this issue reported to law enforcement agencies, which can be explained by the closure of the minority community, as no one speaks openly about this issue. Everyone in the village is aware of underage marriages, but they do not contact law enforcement or NGOs. The problem lies mainly in traditions and stereotypes.

Women in the Kvemo Kartli region are underrepresented in politics, media, law enforcement and medicine. Research has shown that minority women have less trust in male police officers and do not talk to law enforcement about their problems. It is possible that the Covid factor exacerbated this problem, although there is no research on this yet.

People who marry at a young age do not have the opportunity to get an education; this also causes psychological and medical problems. It is common for teenagers to approach medical centres with various gynaecological problems. Besides, they also have psycho-emotional problems. Namely, there is a social and economic factor to all this. Often, people who married at a young age are deprived of educational opportunities. Moreover, a family that is based solely on physiological needs and emotions will sooner or later experience its negative effects.

The reasons for early marriages are various, namely poverty or oppression and violation by parents. "Often a girl creates an illusion for herself that if she is in a different environment she will be better off; however, this is wrong. As a rule, the percentage of break-up of couples who marry at a young age is quite high. The reason for this is that often an adolescent girl finds herself in a harder situation and environment. She becomes a servant to her family members, be it her husband, mother-in-law or father. She becomes obliged to serve the elderly or the children living in the family. Naturally, the girl experiences constant oppression and stress, because she thought she would be in a better environment and found herself in a worse one."

Early marriage limits access to education and thus to employment opportunities. Early marriage is associated with girls dropping out of school; the higher the education level of girls, the lower the early marriage rate. Education dropout during early marriage is determined by factors such as increased family responsibilities, childcare, social factors - gender stereotypes and norms. In general, early marriage promotes social vulnerability. Furthermore, access to education is closely linked to employment; due to the lack of skills and competences necessary for employment, adolescents who marry at a young age find it difficult to obtain stable and highly paid jobs; their incomes are small and unstable. As a result, they face economic difficulties which make them dependent on others.

A special report prepared by the Georgia Public Defender's Office reveals that "as a result of early marriage, children and youth face risks such as domestic violence. They are much more vulnerable and have less information about protective mechanisms. Moreover, they treat violence as a situation with no way out and therefore find it difficult to find a way out, especially if we take into account the current social aspects and requirements in Georgia that derive from the principles of gender inequality, such as the informal requirements set by society for a lady to maintain honesty and chastity, later maintenance of the family and the duty of tolerance."

It should be noted that a psychologist and an educator working alone will not be able to eliminate the above problems; a comprehensive, multidisciplinary approach to these issues is necessary. 


\section{Sharing good practice}

The city service "Peace for Women" is available in Georgia, in different regions. The service aims to empower women living in the region. The Women's Room, an open space for women and not only for women, has been created as new municipal service with the main objective of working with local authorities and involved people, especially women living in rural areas. The above service promotes participation and the achievement of gender equality. The Women's Room offers a variety of services to clients:

- library;

- computer and internet access;

- children's corner;

- information about activities and news of local municipalities;

- information for women;

- special training programs and various education enhancing activities.

In a nutshell, this space helps women to be active and helps to identify leaders.

In some regions of Georgia there is a gender department in the local governments to oversee the protection of human rights and freedoms in the field of gender equality, to promote the integration of gender equality in the regular human rights activities of the local government, to conduct research and raise public awareness to strengthen gender equality at the local level.

\section{Conclusion}

Consideration of gender equality, seen as one of the fundamental human rights, is the responsibility of the Steering Committee on Gender Equality (CDEG).

The State of Georgia Gender Equality Concept "aims to encourage the equal and effective implementation of rights and opportunities for women and men. The concept recognises the principles of gender equality in all spheres of public and social life and provides for appropriate measures for the prevention and elimination of all forms of gender-based discrimination, as well as for the promotion of gender equality." It emphasizes equal political participation, equal employment opportunities and social justice as key factors in these changes.

If this is a long-term action plan for gender equality in the country and is considered positive in international practice, the state should play an important role in addressing the issues of gender inequality in Georgia caused by domestic violence, lack of public services, domestic violence, low awareness as well as early marriage. Gender in minority populated regions remains a problem for women, for their career achievement since the glass ceiling principle hinders their career advancement. Strong inconsistency in the wage budget between men and women is also an important factor.

Women's political participation and representation in parliament is still a big barrier for the country. Gender quota mechanisms are very much needed and it is predominantly the state but also civic, public and non-profit organizations that should address the problem.

If Georgia wants overcome this challenge it needs to take into account all the suggestions and recommendations of international partners. 


\section{Bibliography}

Gender Equality Council Performance Assessment Report (2018), Tbilisi.

Gender-equality-index/2020.

Georgian statistic research document, https://www.geostat.ge/ka.

Law of Georgia on Gender Equality, https://www.legislationline.org/download/id/6780/file/Georgia Law\%20on\%20Gender\%20Equality_2010_am2016_en.pdf.

Lorber J., Farrell S. A. (eds.) (1991), The social construction of gender.

UN Women (2020), Analysis of the Gender Pay Gap and Gender Inequality in the Labor Market in Georgia, Tbilisi, Georgia.

\section{Wyzwania dla polityki równościowej w Gruzji}

\section{Streszczenie}

Badania naukowe potwierdzają, że równość szans dziewcząt i chłopców jest jedną z najważniejszych determinant rozwoju, która ma pozytywny wpływ na postęp we wszystkich istotnych dziedzinach, w gospodarce, polityce i życiu społecznym kraju. Poniższy artykuł łączy interdyscyplinarne badania w celu zbadania ważnych aspektów zasad równości płci w Gruzji w różnych obszarach, w tym zaangażowania politycznego kobiet, kwot i mechanizmów podczas wyborów, przemocy domowej i przemocy wobec kobiet - prewencja, przedwczesne małżeństwo jako forma przemocy. Analizą objęte zostały instytucje publiczne lub pozarządowe zajmujące się tymi zagadnieniami. Autorka dokonała również badania programów państwowych, których programy pomagają obywatelom w zaangażowaniu i rozwoju, upodmiotowieniu kobiet i kobiet wiejskich oraz dobrobytu gospodarczego. Ponadto zbadano gruzińskie ustawodawstwo, a także budżetowanie i programy pod kątem płci. Dane uzyskane z badań dają nam podstawę do wyciągnięcia następujących wniosków: 1) pomimo pozytywnych ogólnych ram prawnych Gruzja nie wywiązuje się w praktyce ze swoich międzynarodowych zobowiązań dotyczących przestrzegania zasad równych praw kobiet i równości płci; 2) system kwot i mechanizmy ulegają w Gruzji stopniowemu polepszeniu; 3) Gruzji wciąż brakuje instytucji świadczących usługi dla ofiar przemocy; 4) nie ma solidnych mechanizmów koordynacyjnych między instytucjami państwa a samorządami lokalnymi; 5) urzędnicy publiczni muszą zdobyć dodatkową wiedzę i doświadczenie w zakresie wrażliwości płci, budżetowania i planowania programów.

Slowa kluczowe: płeć, polityka płci, Gruzja, ustawodawstwo 